\title{
Women Returners and Potential Returners: Employment Profiles and Labour Market Opportunities-A Case Study of the United Kingdom
}

\author{
Jennifer Tomlinson, Wendy Olsen and Kingsley Purdam
}

Women who have previously left the labour market to have children or to care for a family member represent a large proportion of the present and potential workforce. This article innovatively links data on women's education with employers' skill needs and market wage rates to map the different circumstances of women returners in the United Kingdom. We explore whether there is a clustering of women returners in low-wage occupations and how this group can be differentiated. The United Kingdom is a valuable case as it has one of the highest rates of part-time work in Europe. We find that women returners experience high levels of occupational segregation and that these patterns are intensified when they work part-time. Thus, when women returners work part-time, they have limited occupational choice. Rigidities in the design of full- and part-time jobs have led to many women opting for part-time jobs in occupational areas for which they are over-qualified. Additionally, we argue that UK women returners and potential returners have been overlooked in government and sector skill council training agendas. We conclude by commenting on the lack of diversification of part-time work and provide insights for policy makers with respect to the labour market, women returners and potential returners.

\section{Introduction}

In this article, we examine the employment profiles of women who have previously left the labour market to have children or to care for a family member. This group represents a large proportion of the available workforce and includes highly skilled individuals. The skills of whom we term women returners and potential returners are increasingly crucial to economic growth given the demographic shifts evident in most European societies, which include a declining fertility rate and ageing population. Unaddressed, this will result in a smaller labour supply in the future threatening the competitiveness of both the United Kingdom and other European economies (Duncan, 2002; RubsamenWaigmann et al., 2003). As Crompton (2006) and Gambles et al. (2006) note, reconciling care and working time are characteristic of working lives on a global scale. In the United Kingdom, the recently published Women and Work Commission report estimates that 'removing barriers to women working in occupations traditionally done by men, and increasing women's participation in the labour market, could be worth between $\mathfrak{E} 15$ billion

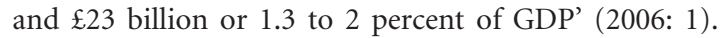


Thus, the importance of opening up the labour market to potential returners and ensuring that those women returners currently in employment are utilized optimally has never been greater.

We focus specifically on the United Kingdom alongside reference to other European countries including Denmark, Sweden, and the Netherlands and also the United States. The United Kingdom presents a particularly important and interesting case study given that it has the second highest rate of part-time working in the European Union and third in the OECD after the Netherlands and Japan (OECD, 2007: 261). Additionally, the structuring and status of the (typically part-time) jobs that women occupy when returning to work after a period of care in the United Kingdom have significant (negative) implications for women. These implications span pay (Walby and Olsen, 2002; England, 2005), skill acquisition (Miller et al., 2004), and occupational mobility (Tomlinson, 2006) as most parttime work, in the United Kingdom at least, is low-paid, low-skilled, and service sector employment that is short in hours and often referred to as 'marginal' work (Blossfeld and Hakim, 1997: 1).

In the United Kingdom, 74 per cent of women aged 16-59 years are economically active (ONS, 2006). The UK labour market has witnessed a dramatic increase in women with very young children returning to work. In 1975 , only 25 per cent of women with a child under 5 years were in employment, while in 2005, this had risen to 56 per cent (EOC, 2005). Of these 66 per cent worked part-time. Additionally, in the context of an ageing population, more workers report elder care responsibilities that have the potential to impact on working time (Crompton, 2006; Gambles et al., 2006). A recent survey of workers in the UK public sector highlighted that around half of all workers reported caring responsibilities but the proportion of female part-time workers taking responsibility for the primary care of a dependent was higher at 64 per cent than for female fulltime workers at 54 per cent (Thornley, 2007).

In employment terms, women who have previously left the labour market to have children can be categorized as returners or potential returners depending upon whether they are economically active or not. In relation to women who have returned to employment, evidence shows they can experience serious difficulties in their attempts to reconcile work and family life. In the short term, downgrading may occur as they adapt to changes at work as a result of changes in family composition. In the long term, this can take place as women attempt to resume careers after a longer period of inactivity or part-time work. For instance, Elliott et al. (2001, 2004) using longitudinal data from the National
Child Development Study have highlighted the differential rates and speed of return of women to paid employment according to the level and type of their qualifications. Women with occupation-specific higher qualifications are much more likely than those with nonoccupation-specific degrees to take maternity leave in the first place and to return to work between the births of a first and second child.

Often when women return to work part-time in the United Kingdom, they have to change employment since many occupational areas in the labour market, particularly those that are male dominated, do not accommodate part-time working or hours that suit childcare arrangements (Liff and Ward, 2001; Lewis, 2001). When women change occupations they often do not fully utilize their past experience, training, and skills and this can have negative consequences for their pay, quality of working life, employment status, and career progression (Manning and Petrongolo, 2004; Tomlinson, 2006).

Despite their importance to the labour market, women returners and potential returners are underresearched groups in terms of their employment profiles and work trajectories. This is particularly the case for women who are currently economically inactive but intend to return to work in the future. Our recent related research has assessed whether skills shortages are concentrated in male-dominated jobs and why wages are so much lower for part-time women returners than for other groups (Tomlinson et al., 2005). Evidence of occupational downgrading was also extensively described and part-time women returners' wages were lower for reasons that were not explained by either human-capital or institutional factors. (Tomlinson et al., 2005, Figures A3.7-A3.9).

In this article, we assess whether there is a clustering of women returners in low-wage occupations. We also examine the extent to which it is important to differentiate between women returners working full-time and part-time. The structure of this article is as follows: first, we contextualize the research by reviewing the literature on family formation, part-time work, and the debates on segregation and occupational downgrading. Second, we describe the data sets and methods used and outline our typology of women returners. Third, we explore the employment and education profiles of women returners and potential returners in the United Kingdom. Finally, we review the government training and skills policy in relation to women returners and potential returners and assess the implications of our findings for policy makers within the United Kingdom and Europe. 


\section{Context: Women's Employment and Family Formation}

The extent to which motherhood leads to greater occupational gender segregation has been widely debated. The institutional context certainly shapes women's likelihood of being clustered into feminized occupational areas when women return to work following maternity or a period of family care (Crompton, 1999). The context varies across different countries and can depend, amongst other things, on the public policies in place, particularly childcare and welfare-state provision, employment regulation, working time patterns, and the quality of part-time jobs (Dex and Walters, 1989; Elliott et al., 2001; Kenjoh, 2005).

Noting variation, England (2005) hesitates in linking segregation directly to motherhood in the United States. She claims:

What generates segregation (and thereby some pay gap) and what generates part of the pay gap linked to motherhood are largely unrelated. Segregation is maintained by social norms on the supply and demand sides - workers' ideas about what jobs are appropriate for them and employers' preferences. Economists hypothesize that women are in the jobs that fit the average women's childrearing responsibilities best, but also make women pay something for the mother-friendliness of their jobs. This does not fit the data well... at least in the United States. (p. 281).

The qualification made here is important since, in the United States, mothers are much more likely to work full-time than mothers in the United Kingdom (Elliott, 2005; Tomlinson, 2007).

In a European context, diversity in the use and structuring of female part-time work is also evident. For example, in Denmark and Sweden, shorter fulltime hours make full-time working more feasible for workers with care responsibilities and part-time work is longer in duration and less marginalized in terms of its location in the labour market. While service and sale occupations are common part-time jobs in Denmark and Sweden, these countries have higher proportions of skilled, technical, and professional parttime jobs available than in the United Kingdom (European Commission, 2002).

In Denmark and Sweden, maternity does not mark such a definitive shift into occupational areas that are highly feminized, low paid, low skilled, and part-time (Horrell et al., 1990; Burchell et al., 1997; Grant et al., 2005). In the United Kingdom, however, as Blackwell (2001) notes, there is a strong relationship between mothers returning to the labour market and at the same time making a transition to part-time work, which is much more acutely segregated by gender, than full-time jobs are. Blackwell (2001) states that it is usually motherhood that precipitates a shift from full-time to part-time work and that 'women who switch from fullto part-time work were most likely to also switch to more feminized occupations' (p. 147).

The structuring of part-time work in the United Kingdom is such that women working part-time usually work in low-status jobs. The statement that 'moves towards opening up management jobs on a part-time basis' in the 1990s were slow and 'embryonic' (Burchell et al., 1997: 215) remains the case a decade later. The proportion of female parttimers employed in managerial positions is calculated as being just 4.4 per cent (Manning and Petrongolo, 2004: 5). This results in part-time jobs, which are taken predominantly by women, leading to the persistence of both horizontal and vertical forms of segregation (Cockburn, 1988) as part-time work is highly clustered into feminized occupational areas and rarely found in male dominated ones. Vertical segregation occurs since most part-time work is located towards the bottom of organizational and occupational hierarchies, where the poorest terms and conditions of employment are found. Confirming this, Blackburn et al.'s (2000) analysis of the intersection of inequality and segregation shows that it is the 'vertical dimension of segregation that measures gender inequality' most accurately (p. 131). Part-time work is, therefore, crucial in maintaining both patterns of segregation and inequality in the United Kingdom.

Whether women genuinely prefer low-skilled parttime jobs has long been a matter of contention. In the case of the United Kingdom, Hakim (1996, 1997, 2000) has argued that women who choose to work part-time do so because they have qualitatively different lifestyle/sex role preferences, compared with men and women working full-time, which shape their orientations to work and location in the labour market. She claims that female part-time workers demonstrate a preference for work that is less demanding and are therefore largely satisfied with low-status part-time employment.

Alternatively, Rose (2001) argues that it might be that women concede an acceptance of, rather than a preference for, the part-time jobs that they occupy. 
Likewise, Fagan (2001) claims that women's working hours are largely out of step with preferences in the United Kingdom. She found that 45 per cent of female full-time workers stated a preference for a reduction in their working hours, and 25 per cent of women working fewer than $16 \mathrm{~h}$ per week wished to increase their hours of work. As such, the design of jobs in the UK labour market is often 'out of step' with women's preferred working hours whereby they may take or accept short, marginal part-time jobs over long fulltime employment without genuinely preferring, or wanting, low-status, low-skilled work for which they may be over-qualified.

Over-qualification among working mothers is often thought to be the result of a process of occupational downgrading whereby women opt for part-time work and accept jobs beneath their capabilities and qualifications (Grant et al., 2005). Put simply, their human capital is under-utilized. This phenomenon has been documented for some time now, particularly in qualitative studies. Typically, it occurs when women face changes to their grading, job, or occupation because they wish to switch to part-time hours following maternity (Macran et al., 1996). This can lead to ineffective use of women's skills (Gallie, 1996). As Dex and Joshi explain:

Part-time openings have been mostly in low level occupations. Many women trade down, accepting a convenient job with reduced hours but lower status, as a way of combining family responsibilities with income-generating employment. (1999: 649).

However, much evidence on occupational downgrading is anecdotal and is set alongside research on part-time work and returns to employment among mothers, without actually being a central part of the research analysis (McRae, 1993, 1994; Jenkins, 2004; Walters, 2005). Quantifying occupational downgrading is challenging for several reasons. First, it may occur at different times in women's employment trajectories. Some people may experience downgrading following a return from maternity after their first child, others later after a period of activity or after a second or third child. It is also the case that over their life course, women may eventually regain an occupational status commensurate to their position prior to maternity. However, despite these caveats, nearly half of employed mothers in the United Kingdom with a child under 5 years are thought to be in jobs that under-utilize their skills (Women and Work Commission, 2006). We explain our methodology and examine the results of our analysis subsequently.

\section{Methodology and Data}

Innovatively, this article combines analysis from three separate data sets: the British Household Panel Survey (BHPS) (BHPS, 2007) for work-life histories going back many years for each woman; the Labour Force Survey (LFS) (ONS, 2001) for accurate coverage of small occupational sub-groupings; and the Employers Skills Survey (ESS) (ESS, 2001) for information about the level of formal education and skills perceived to be required for particular jobs in well-defined sub-groups. The LFS was linked to the ESS to create a large and detailed data set with a dual unit of analysis-the person and the 'job'.

This approach allows us to examine diversity within the female population in the United Kingdom in terms of their education and employment profiles, their hours of work, pay, and likelihood of working in areas of high-occupational gender segregation. While other research on women returners has categorized these women as a group irrespective of their full- or parttime employment status (Dooreward et al., 2004), we explore heterogeneity within the women returner category. As Elliott (2005) states, disaggregating women by full- and part-time employment is particularly important in moving beyond 'dichotomous measures', particularly in terms of occupational gender segregation.

\section{Definitions and Time Period}

The BHPS offers an ideal opportunity to examine long-term career profiles since it is a panel data set (1990-1991 to present) and had 12,500 respondents in the year 2001-2002. Adults are also included in its annual work-history update and are interviewed regardless of whether they were employed or not in that year. The panel was used in two ways in this research. First, each person's work history was compiled, including a recall segment that the 1991-1992 and 1992-1993 respondents provided for their last job and current job, as well as the annual update recall material on employment status and occupation (which included part-time working) for each year after that. The work-life history was broken down into its component parts such as employment, retirement, unemployment, and inactivity (Olsen and Walby, 2004). The part-time months were taken as a ratio to the total employed time inclusive of selfemployment.

Second, the BHPS panel data were used to determine which type of returner a woman was (Table 1). 
Table 1 Summary statistics: types of women workers in the United Kingdom

\begin{tabular}{|c|c|c|c|c|c|c|c|c|}
\hline $\begin{array}{l}\text { Population, } \\
\text { wave K, } \\
2001-2002\end{array}$ & $\begin{array}{l}\text { Working } \\
\text { age } \\
\text { POP (\%) }\end{array}$ & $\begin{array}{l}\text { Average } \\
\text { hourly } \\
\text { wage }^{b} \\
\text { (f) }\end{array}$ & $\begin{array}{c}\text { Average } \\
\text { hours } \\
\text { worked } \\
\text { per week }\end{array}$ & $\begin{array}{c}\text { Average } \\
\text { percentage } \\
\text { males, } \\
\text { in their } \\
\text { occupation (\%) }\end{array}$ & $\begin{array}{l}\text { Average } \\
\text { years of } \\
\text { education }\end{array}$ & $\begin{array}{c}\text { Woman who have } \\
\text { a dependent } \\
\text { child (\%) }\end{array}$ & $\begin{array}{l}\text { Part-time } \\
\text { work as a } \\
\text { percentage } \\
\text { of the work } \\
\text { careerc }(\%)\end{array}$ & $\begin{array}{c}\text { Without a } \\
\text { level } 2 \\
\text { qualification } \\
(\%)\end{array}$ \\
\hline \multicolumn{9}{|l|}{ Actual returners } \\
\hline $\begin{array}{l}\text { Mothers employed } \\
\text { part-time }\end{array}$ & 7 & 7.09 & 17.75 & 25 & 12.4 & 100 & 45 & 13 \\
\hline $\begin{array}{l}\text { Mothers employed } \\
\text { full-time }\end{array}$ & 6 & 8.58 & 37.31 & 36 & 12.7 & 100 & 21 & 11 \\
\hline $\begin{array}{l}\text { Recent returners } \\
\text { (Now employed } \\
\text { part-time) }\end{array}$ & 2 & 6.94 & 15.48 & 26 & 12.1 & 79 & 38 & 20 \\
\hline $\begin{array}{l}\text { Recent returners } \\
\text { (Now employed } \\
\text { full-time) }\end{array}$ & 0.5 & 6.57 & 35.62 & 32 & 12.1 & 71 & 30 & 7 \\
\hline All recent returners & 2 & 6.79 & 21.4 & 27 & 12.1 & 76 & 35 & 15 \\
\hline \multicolumn{9}{|l|}{ Potential returners } \\
\hline $\begin{array}{l}\text { Mothers doing } \\
\text { caring work }^{\mathrm{a}}\end{array}$ & 5 & - & - & - & 11.1 & 100 & 22 & 61 \\
\hline $\begin{array}{l}\text { Mothers not doing } \\
\text { caring work }^{\mathrm{a}}\end{array}$ & 3 & - & - & - & 11.6 & 100 & 26 & 52 \\
\hline $\begin{array}{l}\text { Other inactive } \\
\text { women }\end{array}$ & 8 & - & - & - & 11.1 & 0 & 28 & 62 \\
\hline All women & 52 & 7.91 & 30.5 & 32 & 12.2 & 42 & 28 & 43 \\
\hline All men & 48 & 10.27 & 41.2 & 68 & 12.4 & 37 & 3 & 35 \\
\hline
\end{tabular}

Source: BHPS 2001-2002, and BHPS Work-Life History Data Set 2002, updated using BHPS annual work-history data. Base: 10,543 people (raw), 9365 (weighted). The population: all women and men in Great Britain except those who are self-employed, in the age group 16-59 for women, and 16-64 for men.

${ }^{a}$ 'Mothers' here refers to women with dependent children in Wave K, 2001-2002.

${ }^{b}$ The hourly wage rates are gross hourly rates including bonuses and overtime payments. They are adjusted for tax credits.

${ }^{c}$ The work history using BHPS covers 1991-2002 to 2001-2002. The sum of months worked part-time is taken as a percentage of the months worked during that work history, inclusive of a recall period of varying lengths among those present in 1991-1992 and/or 1992-1993; see also Olsen and Walby (2004).

An actual returner is a woman who has gone back to work either full- or part-time while having at least one dependent child in the household in 2001-2002. This group is named as such since they have already returned to the labour market and have been for some time. When using BHPS data, actual returners may be simply referred to as mothers working full- or part-time. ${ }^{1}$ However, please note in this context the term 'mothers' in Table 1 excludes those female parents whose children do not live in the same household.

In order to map any variations within the actual returner category we also identified recent returnerswomen who have made a recent transition back to work following a period of maternity or family care. ${ }^{2}$ A recent returner in the BHPS was defined as a woman who was employed at some time in the 10 years between 1990-1991 to 2000-2001, following which she left the labour market to undertake family care work for at least one of the 5 years from 1996-2000, thus resulting in a gap in employment; and then was back in employment in 2001-2002.

Contrasting with these two groups of employed women, we define potential returners as women who are currently economically inactive. Some are women with children who have caring responsibilities as their main daily activity and who have no paid employment. However, there are other sub-types of the potential returner: those who have one or more dependent children but do not claim to have caring responsibilities; and also those who are currently without dependent children and are not employed. Some of these women are engaged in study and some have an illness or disability.

The full work history was compiled only for those longitudinal respondents who were in the survey in 2001-2002. ${ }^{3}$ A long-term recall work history was acquired in 1991-1992 and in 1992-1993 from original 
survey respondents of Wave A and those who joined in Waves B and C. These recall work histories describe the work history including the start of the job or other episode of work that the person was in during the Wave $\mathrm{B}$ or Wave $\mathrm{C}$ cycle of the BHPS. We updated the worklife history data to include the years 2000-2001 and 2001-2002, keeping part-time paid work separate from full-time paid work as far as possible. ${ }^{4}$ The BHPS data for 2001-2002 were then weighted using cross-sectional weights that adjust for the non-response due to both prior attrition and refusal in that wave. The weights used allow the survey to represent the 2001-2002 populations of England and Wales and Scotland (including the Scottish and Welsh booster samples).

The LFS was analyzed by creating a pooled data set consisting of four separate cross-sectional samples, dated 2001-2004, ${ }^{5}$ reflecting our attempt to describe all occupational groups' educational background and other characteristics. Each quarter consisted of around 8,000 respondents leading to a pooled data set with about 40,000 cases. Of these, only male and female employees were used for this study, so retired people and those who were self-employed were excluded. The total raw sample size of women workers in our analysis was 14,448 after excluding selfemployed women. The corresponding weighted population of working women is $11,011,000$.

The LSF variables for occupation [Standard Occupational Category (SOC) at the two-digit level] and for industrial sector [Standard Industrial Classification (SIC) at the one-digit level] were crossclassified, giving 125 categories which we call 'jobs' or occupational sub-groups. ${ }^{6}$ Using cross-sectional weights from all four parts of the pooled data set, re-weighted to give each year equal weight in total, we calculated averages for a variety of variables-such as gender of employee (percentage male) and formal education in years-across the whole period for each occupational sub-group. These means are reported in Tomlinson et al. (2005; Appendix 2) along with details of how each variable was derived. The variable 'years of education' was recoded from specific qualification details, with education below level 2 defined as 8 years of schooling; level 2 education as 9 years; level 3 as 11 years; and above level 3 as 14 years. Level 2 education is defined internationally and, for the United Kingdom, refers to 5 or more General Certificate of Secondary Education (GCSE) passes at grades A-C, or 5+ O-level passes, or one A-level, or similar. Level 3 refers to 1 or more A-level, and degree holders are considered to be at level 4 .

The ESS 2001 survey involved 27,031 telephone interviews from November 2000 to April 2001 sampled from all business establishments or local units in England with one or more employees. The ESS occupational data set was used, which contains 14,470 occupations in which a vacancy was reported (ESS, 2001). The weights for vacancies were applied to create results representative of England's occupational structure. Vacancy-based weights are used because after asking about vacancies of a certain type (and skills shortages in those jobs), the number of such vacancies was also recorded for each business establishment. This is an efficient way of calculating nation-wide means, and the ESS weights also adjust for non-response at the business level. The averages for each occupational subgroup (again cross-classified by SOC and SIC) were copied across to each individual in the LFS. We then calculated the weighted mean for each occupational sub-group in the LFS for variables arising originally in the ESS, such as the degree of skills shortage or the expected level of education of applicants to each job within its sub-group. Data from ESS for the year 2003 have been reported on but were not in the public domain at the time of the research, so the year 2001 is the central time-point to which we refer in our linked data analysis.

The LSF data used in this research covered the whole of the United Kingdom, i.e. including Scotland and Northern Ireland, but in order to create comparable measures Northern Ireland was excluded. The Employers Skills Survey 2001 covered only England. In summary, means and correlations produced from the BHPS data set are representative of Great Britain on major demographic variables, but the work-life history data for each 2001-2002 individual inevitably will reflect attrition bias and a slight undercount of work episodes due to temporary missing individual respondents. No assumptions were made about the work status of the individual during any year in which they were absent without proxy data from the BHPS.

\section{Results: Employment Profiles of Women Returners and Potential Returners in the United Kingdom}

\section{Qualifications and Pay}

Overall, women returners working full-time are likely to work in occupational areas with less gender segregation and earn more than women returners working parttime. They are also better qualified, significantly so, if the two 'recent returner' (full- and part-time) categories 
are the unit of analysis. This confirms, as others have argued, that it is highly qualified women who return quickly to full-time employment after maternity (Macran et al., 1996; Dex and Joshi, 1999; Elliot et al., 2004). Similarly, Fagan et al. (2002) note that the impact of motherhood on employment is much less pronounced for women with high qualifications. For example, mothers with high levels of qualifications have higher employment rates than less qualified women without children. The profiles of the different women returners in the United Kingdom are set out in Table 1.

Our analysis reveals huge differences in the education profiles of women returners in employment and potential returners who are currently economically inactive. Of those in the potential returner category, 'mothers doing caring work' and 'other inactive women' are much less likely to have a level 2 qualification (61 and 62 per cent, respectively, did not have a level 2 qualification). Amongst recent returners, of those employed full-time, 7 per cent did not have a level 2 qualification and amongst parttimers 20 per cent did not have a level 2 qualification. ${ }^{7}$ Thus women who become actual returners in the United Kingdom, on average, have higher educational qualifications than women outside the paid labour market.

Table 1 also highlights the hours worked by women returners. In other EU countries, such as the Netherlands and Sweden, there are smaller distinctions between the working hours of women employed fulltime and part-time (European Commission, 2003). Our results show that actual women returners employed full-time work on average $37.31 \mathrm{~h} /$ week, while those employed part-time work just $17.75 \mathrm{~h} /$ week. This indicates that distinctions between full- and part-time jobs remain stark in the United Kingdom, which is highly likely to influence the types of jobs that are constructed as full- or part-time.

Women returners employed part-time earn on average $\mathfrak{E} 7.09$, which is $\mathfrak{E} 1.49$ less per hour than their full-time counterparts. In addition, while recent returners employed full-time can expect to see their pay increase by $£ 2.01$ per hour if they maintain a fulltime trajectory, part-timers can expect a much smaller increase of $\mathfrak{E} 0.15$ per hour if they maintain a part-time profile.

\section{Occupations}

The occupations of women returners employed fulltime and part-time in the United Kingdom are shown below. As described above, we have used pooled LFS data for 2001-2004. Figure 1 reveals that most UK mothers who are employed part-time are highly concentrated in 'administrative occupations', 'caring personal service occupations', 'elementary administration \& service occupation', and 'sales \& customer service occupations'. They are highly unlikely to work as 'corporate managers' and totally absent from the 'skilled construction \& building trades' occupation. They are also virtually absent in other science, engineering and technology (SET) occupations, which are often highlighted as being the most persistently male dominated and areas suffering the highest skill shortages (Ruiz, 2004). It appears that employed mothers, if they have a preference for part-time hours, do not at present have much choice over the occupational area in which they work.

Our results are consistent with Burchell et al.'s (1997) analysis of the 1991 Census data, where the majority of part-time work was clustered into the three occupational categories of: 'sales occupations', 'clerical and secretarial occupations', and 'personal and protective occupations' (Burchell et al., 1997: 214; see also Elliott et al., 2004). The similarities are of concern since while there is a larger proportion of women returners active in the labour market compared to a decade ago (EOC, 2005), there has been little change in the occupational locations in which these women are found, which remain some of the most poorly paid and low skilled.

Women returners employed full-time are found in a wider range of occupational areas. As Figure 2 shows, while mothers who are employed full-time are still likely to be working in 'administrative occupations' or in 'caring personal service occupations', they are also much more likely to be working in highly skilled occupational categories such as 'corporate managers' and 'teaching \& research professionals', and intermediate occupational categories such as 'business \& public service associate professionals' than mothers who are employed part-time. Indeed, mothers employed full-time are more than four times as likely as mothers employed part-time to be working as corporate managers. It is likely that this is, in part, due to the job design of more senior graded jobs, particularly managerial positions, most of which rarely accommodate part-time working.

Our findings lend support to Blackwell's (2001) contention that motherhood often precipitates a transition to part-time employment which intensifies gender segregation in the United Kingdom. On the surface our findings also support Fagan's (2001) research on the design of full- and part-time jobs in that it appears mothers make trade-offs between being 


\section{Occupational status of women returners employed part-time}

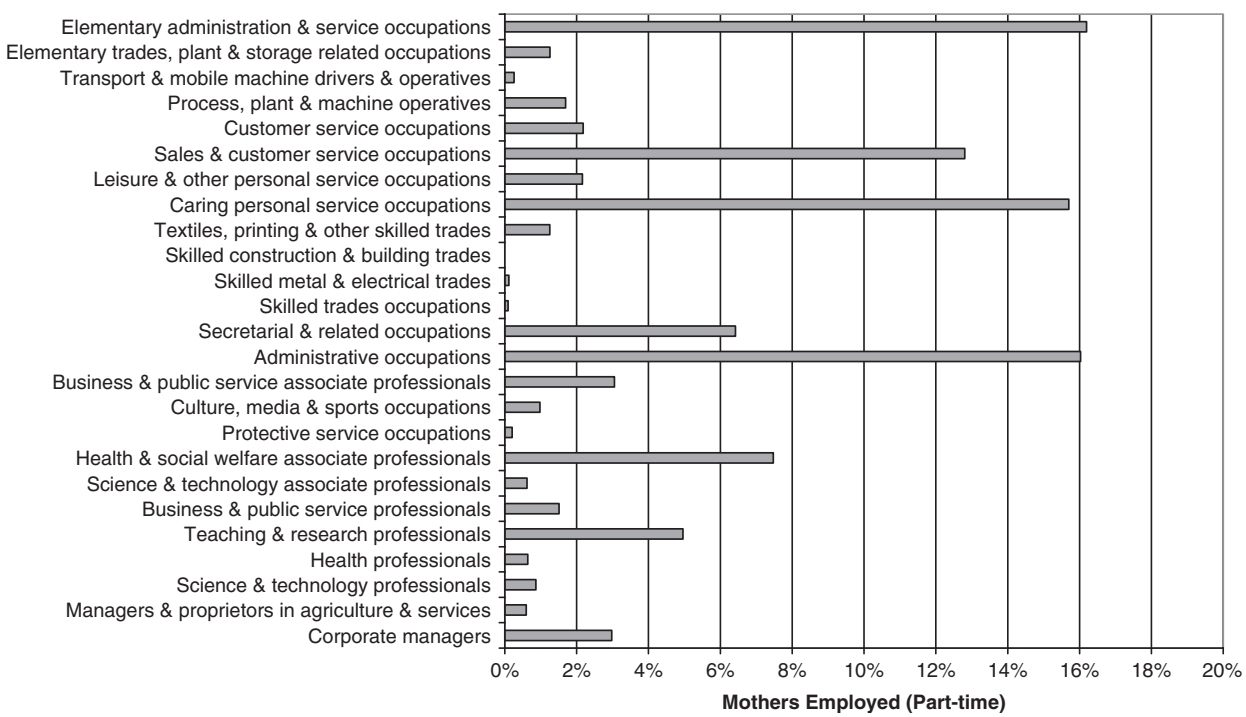

Figure 1 Occupational status of women returners working part-time. Base: 3448 (raw), 2,524,910 (weighted); Population: all part-time employed mothers in Great Britain except those who are self-employed, in the age group 16-59 years. Occupations as classified under the Standard Occupational Classification 2-digit code. Mothers employed part-time: women who work part-time (up to $30.4 \mathrm{~h}$ a week) and have at least one child aged 0-16 years. Source: Pooled Longitudinal Labour Force Survey data March 2001-May 2004.

\section{Occupational status of women returners employed full-time}

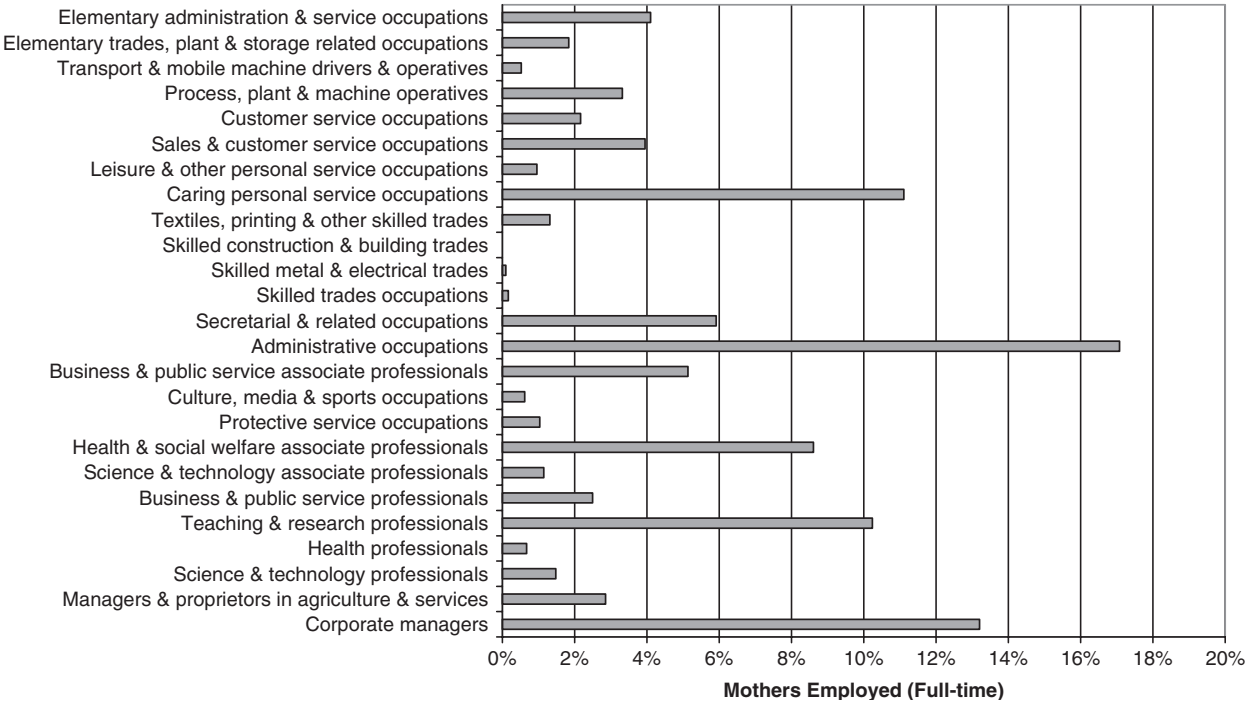

Figure 2 Occupational status of women returners working full-time in the United Kingdom. Base: 2060 (raw), 1,525,017 (weighted); Population: all full-time employed mothers in Great Britain except those who are self-employed, in the age group 16-59 years. Occupations as classified under the Standard Occupational Classification 2-digit code. Mothers Employed full-time: women who work full-time (more than $30.4 \mathrm{~h}$ a week) and have at least one child aged $0-16$ years. Source: Pooled Longitudinal Labour Force Survey data March 2001-May 2004. 
satisfied with their hours of work or alternatively working long hours while retaining a better occupational status. As Rose (2001) has suggested, in this sense many women working part-time may accept their jobs rather than genuinely prefer them. Indeed our research supports such a proposition for the United Kingdom in that women returners employed full-time work more than twice as many hours as women returners who are employed part-time. Though many women indicate a preference for longer parttime hours or shorter full-time hours, these jobs are currently lacking in the UK labour market.

The notion of a trade-off may well have substance as we found that many women who opt for part-time hours are often over-qualified for the jobs they are employed to do (Tomlinson et al., 2005). Our analysis of the ESS suggests that women returners were likely to be over-qualified, according to employers' views of necessary qualifications compared with women returners' actual qualifications in four occupational areas. These were 'administrative occupations', 'secretarial \& related occupations', 'sales \& customer service occupations', and 'elementary \& service occupations'. These are precisely the places where women work when they are employed part-time.

Of all mothers who work part-time, 67 per cent work in occupations which have over-qualification-this figure amounts to 1.5 million workers in total. These over-qualified workers amount to 23 per cent of all the women in those particular occupations. The average level of over-qualification in 2001 in these five occupations was 2.2 years. This result demonstrates that women are shifting to occupational areas that tolerate part-time work, however, many women working in these areas have higher qualifications than the aggregate average for all employees in these occupational areas.

In the United Kingdom, the government's White Paper "Realising Our Potential" (1993) states that more women should be targeted as a potential human resource for SET occupations. Additionally, it has been proposed that if the European Union is to achieve its targets on science and innovation, then tens of thousands of scientists and research professionals are needed, many more than can be provided through universities alone (Rubsamen-Waigmann et al., 2003). Women's skills and the retention of them over the life course, particularly after maternity, is recognized in the policy literature as increasingly important in these occupations, yet as we have shown only a small proportion of mothers employed part-time $(<1$ per cent $)$ and full-time $(<2$ per cent), are employed as science \& technology professionals and even fewer are found in SET trade occupations.

As shown in Table 2, it is these same occupations that are suffering some of the highest skills shortages.

It is also the case that women with SET degrees have a lower economic activity rate than either men with SET degrees or women with non-SET degrees (Miller et al., 2004). Few UK women return to SET occupations after maternity or a break from the labour market which is mirrored in the statistic that just 25 per cent of women with SET graduate qualifications are currently working in SET occupations (DTI, 2002: 6). The 'brain drain' (Ackers, 2007) of women in SET is made all the more acute in light of the fact that these are the occupational areas most likely to report skill shortages. The Helsinki Group (2002) calculated that as many as 50,000 economically inactive women in the United Kingdom have SET degree level qualifications.

\section{Locating Women Returners and Potential Returners in Education and Training Policy}

Recent education and training policies are outlined in the UK Government's DfES White Papers and more recently through the formation of Sector Skills Councils (SSCs) and their agreements. We reviewed the content of both the DfES and SSCs in order to examine the extent to which women returners and potential returners have been recognized as groups facing particular barriers to education and training given their time out of the labour market and in some cases, very low-qualification profiles. The review follows the initial claim in the 1993 Government White Paper 'Realising our Potential' that women are the United Kingdom's single most undervalued human resource. A second point made in the same White Paper was that more women should be targeted to be retained to work in SET occupations given the EU targets for science and innovation.

Our review of policy documents reveals that the dual agenda of dealing with problem of the underutilization of women returners' skills and raising these women's education and skill profiles so that they are better equipped to work in SET occupations has been sidelined in recent years. First, policy initiatives aimed at addressing the particular training requirements of women returners are not evident in recent DfES White Papers. While the DfES Skills in England (2003) publication recognizes that access to training is uneven across various employed, unemployed, and 
Table 2 Male-dominated occupations and skills shortages in the United Kingdom

Occupation

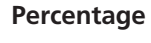

male in

occupation

\section{Segregation}

rank
Skills-shortage

index
Skills-shortage

rank

$\begin{array}{lllll}\text { Science \& technology professionals } & 85 & 6 & 2.7 & 3 \\ \text { Science \& technology associate professionals } & 79 & 8 & 2.7 & 2 \\ \text { Skilled construction and building trades } & 99 & 1 & 2.9 & 1 \\ \text { Skilled metal and electrical trades } & 99 & 2 & 1.1 & 7\end{array}$

Note: Column 2 gives the rank of the occupation's average percentage male during 2001-2004 Labour Force Survey data among the 25 two-digit occupations of the SOC 2000 classification system. The skills-shortage index in columns 3 and 4 divides the number of skills-shortage vacancies by the number of jobs. A skills-shortage vacancy is a hard-to-fill vacancy which is reported by employers to be hard to fill due to a skills-related factor. Source: Tomlinson et al. (DTI, 2005; Figure A3.1). See also Ruiz (2004: 106). Original data from the national Employers' Skills Survey 2001 and the UK Labour Force Survey 2001.

inactive groups, women returners and potential returners do not feature as groups that face a disproportional risk of being excluded from the gains made by the wider population in training and skill development. In the more recent DfES (2005) White Paper 'Skills: Getting on in Business, Getting on at Work' the government sets out how they intend to improve the national skills performance in Britain. Again in this White Paper 'priority' groups are elaborated. Women returners and potential returners in the United Kingdom again were not directly targeted as groups where training policy initiatives need to be focused.

These policy documents also fail to state whether women or men are more likely to be excluded from education and training. Women and men may have different education and training needs. For instance, older generations of women are particularly likely to have no qualifications compared to their male peers (Walby, 1997). Moreover, there is a failure to explicitly recognize that childcare and care for other family members is disproportionately undertaken by women, which has the potential to limit the time they can spend investing in human capital. Women returners, who would be likely to benefit from re-training due to periods of inactivity and potential skill depreciation and potential women returners consistently fall through gaps in government skills and training agendas. This is despite the fact that this latter group of women can have very low levels of qualifications. Unless they are active in the labour market it seems that such women remain invisible to such agendas and remain a relatively untapped resource.

In the United Kingdom, skill and training agendas are now being negotiated through SSCs, which are designed to give employers a 'a stronger voice in shaping the supply of training at every level-nationally, regionally, locally, and in each sector of the economy' (DfES, 2005: 9). Two central priorities of the newly formed SSC are: first, the up-skilling and training of current employees within the workforce and second, securing an adequate future labour supply. To achieve the second SSCs emphasize the need to encourage school leavers and college graduates to opt for these occupational areas, often through the route of apprenticeship schemes (DTI, 2006).

SSCs are expected to try to recruit future workers from a more diverse background than has historically been the case. One SSC with high rates of skill shortages, hard to fill vacancies and high levels of occupational gender segregation is ConstructionSkills, which covers the occupational areas of construction and building trades. ConstructionSkills states in its early document on challenges facing image and recruitment that, 'construction companies will simply not be able to meet their targets by recruiting solely from their traditional pool of white young men' (ConstructionSkills, 2005: 2). However, the document does not set out any strategy for fulfilling this intention. Rather, the SSC moves on to identifying the skills issues that must be addressed' in the years ahead. Focusing on encouraging more women and minority groups to enter construction is fleetingly mentioned, but the Agreement states that central issues to be tackled are 'brushing up the industry's existing skills' and 'stepping up the quality and quantity of new entrants' (SSDA, 2004: 29). This is primarily to be achieved through apprenticeships, which have been introduced through the DfES to raise the qualification profile of young adults to at least a level 2 qualification (DfES, 2003, 2005). However, the same apprenticeships that have been taken up by young men and women are highly segregated in that very few young women and men enrol on apprenticeships that are non-traditional 
for their gender. In construction only 3 per cent of apprentices are females (SSDA, 2004: 21).

Whilst some good practice within certain SSCs has been identified in recent research (DTI, 2006), most of the 'good practice' focuses on recruiting young women and girls to engage in a non-standard career. For example, ConstructionSkills suggests targeted funding for apprenticeships for 'atypical groups' and e-Skills UK's primary activity is based on rolling out its Computer Clubs for Girls scheme (DTI, 2006: 7). A different approach is taken by SummitSkills, which aims to explore the possibility of recruiting unemployed women to train and work as plumbers (DTI, 2006: 8, 86). These strategies focus on the recruitment, but not the retention, of women in these occupational areas. Other reports commissioned by the government and the EOC (Peters et al., 2003; Miller et al., 2004; Women and Work Commission, 2006) have suggested that initiatives to make SET and Construction more attractive to women returners should include flexibility in working-time arrangements and job redesign but these issues are not currently addressed in the SSC documentation.

In the United Kingdom, employers do not, as yet, appear to be committed to adopting practices to encourage women to work in areas of high-gender segregation, particularly in SET (Mackenzie et al., 2000; Dainty et al., 2000, 2001; Singh and Vinnicome, 2000). It is, though, these same employers that are set to become an 'authoritative voice' (DfES, 2005: 16) in shaping the working practices, training, and skill policy within these occupational areas. It is clear that in the United Kingdom, policies on the training and the upskilling of the workforce are limited and have the potential to be further undermined by employers who do not appear to recognize the value of a diverse workforce or neither have the infrastructure nor culture to develop one.

\section{Conclusions}

Women returners and potential returners represent a large proportion of the actual and potential workforce in the United Kingdom and include highly skilled individuals. Our findings suggest that women returners in the United Kingdom face difficulties in working in areas of high-gender segregation and the notion of occupational downgrading is certainly one that implies women returners are likely to work below their potential. Moreover, when employed mothers require part-time hours, they appear to have little choice over the type of occupations in which they work. Women returners employed full-time are likely to work on average more than twice the number of hours per week than woman returners working parttime. These inflexibilities in the design of full and parttime jobs may be leading to scenarios where women opt for part-time hours in occupational areas for which they are over-qualified.

It would seem that the concerns that women are an undervalued human resource in the United Kingdom are well founded. The education and employment profiles of employed and economically inactive women are diverse. Therefore education and training policies aimed at targeting the specific needs of women returners and potential returners need to be established if women's skills are to be utilized effectively. For example, while surveys have shown that many economically inactive women would like to become employed (Women and Work Commission, 2006), our analysis shows that of those considered 'potential returners' 61 per cent do not have level 2 qualifications, compared with 43 per cent of all women and 35 per cent of all men (Table 1). To date, the training needs of women returners have not been widely recognized in the United Kingdom. Explicit and formal recognition that women returners and potential returners are currently overlooked in training and skill policy is important if policy makers are to establish ways to utilize the education, training, and work experience that many women have.

Part-time work among working mothers is becoming increasingly commonplace in the United Kingdom, especially since more women are returning sooner to the labour market after maternity. The diversification of part-time work, so that it is not clustered into a few low-paying, feminized occupational areas, is central in reducing segregation and improving the quality of many women returners' employment prospects. Likewise, promoting part-time work in a broader range of occupational areas is crucial if women are to avoid being over-qualified for the jobs they are employed to do when they return to the labour market. In the current climate, there are high levels of skill gaps in male-dominated occupational areas but little is being done to enable women to re-train to work in these occupational areas. Further research into the training requirements of potential returners and women returners might be beneficial if we are to understand the employment aspirations of returners and potential returners and the how to harness their skills more effectively. As yet, little research of this kind has taken place in the United Kingdom or European Union.

Finally, as we have shown, locating women returners in survey data in the United Kingdom is a difficult 
challenge methodologically and panel data are often the only means through which they can be accurately tracked as taking a break from employment and later returning to the labour market. Further research is required to examine the ways in which women returners and potential returners can be defined and tracked in data sets so as to facilitate a fuller exploration of their characteristics and profiles. It would be advantageous to develop further in-depth research into the incidence of downward occupational mobility when women transfer from full-time work to part-time work and the resultant under-utilization of women returners' skills. Such areas of research are increasingly important since the under-utilization of women returners' and potential returners' skills have detrimental outcomes not only for the individuals themselves, but also for the organizations in which they work(ed), areas of the labour market reporting skill gaps and subsequently, the productivity of the UK economy and the European Union more widely.

\section{Notes}

1. A difficulty arises with using the 2001-2002 data on dependent children living with the woman. Some women who had maternity leave are here labelled 'returners' when in fact, technically, maternity leave in itself is not an interruption of the work career. The data we used from BHPS does not distinguish this kind of worker as a subgroup of the category of 'actual returners' because it cannot be done in a consistent way over the whole life course. Data about maternity leave for children born much earlier than 20012002 may not be recorded in the BHPS data set.

2. See note 1 caveat, which applies to recent returners too.

3. All the waves from $\mathrm{A}$ to $\mathrm{K}$ were used, covering the years 1990-1991 to 2001-2002. The sample for 2001-2002 consisted of 4,850 men of the age of $16-64$ years and 5,693 women of the age of 16-59 years.

4. Part-time employment was more frequently noted for employees than for self-employed workers, for example. The default for an episode was assumed to be full-time unless part-time work was specified. Where a single year of evidence was missing, due to a year's missing data for that person, imputed or proxy data have been used by the BHPS. If the person was still in the survey in 2001-2002, we checked the data for 2001-2002 to ensure that any months of part-time work shown in that year's work-life history data were included in the person's lifetime overall work history.

5. Four annual quarterly Longitudinal LFS data sets dated March 2001-May 2004, ages 16-59. Specifically, the Longitudinal Survey from December 2001-February 2003 (2nd wave; SN4670), from June 2002-August 2003 (4th wave; SN4768), from September 2002-August 2003 (3rd wave; SN 4807), and from June 2003February 2004 (4th wave; SN 5045).

6. There are 26 two-digit SOC categories and 9 onedigit SIC categories. Some combinations were empty.

7. Level 2 education is defined here as having passed five GCSEs at grades $\mathrm{A}^{*}-\mathrm{C}$, or equivalent; level 3 involves passing at least two A-Level at pass grades, or equivalent; and 'above level 3' refers to a degree or higher qualification. Level 1 contains those who did not pass five GCSE exams. The GCSE exams are currently taken in England and Wales at about age 16 years, and up to 10 GCSE exams can be passed at that age.

\section{Acknowledgements}

This research was completed as part of the background research for the Women and Work Commission on behalf of the Department for Trade and Industry and Women and Equality Unit. The authors would like to also acknowledge the support of Daniel Neff and Smita Mehta at the Centre for Census and Survey Research at Manchester University who assisted in the data analysis.

\section{References}

Ackers, H. L. (2007). Legislating for equality? Working hours and progression in science careers. European Law Journal, 13, 169-185.

BHPS (2007). British Household Panel Survey: Waves 1-15, 1991-2006, 3rd edition. Colchester, Essex: UK Data Archive.

Blackwell, L. (2001). Occupational sex segregation and part-time work in modern Britain. Gender, Work and Organization, 8, 146-163.

Blackburn, R. M., Jarman, J. and Brooks, B. (2000). The puzzle of gender segregation and inequality: a cross national analysis. European Sociological Review, 16, 119-145. 
Blossfeld, H. P. and Hakim, C. (1997). Introduction: a comparative perspective on part-time work. In Blossfeld, H. P. and Hakim, C. (Eds.), Between Equalization and Marginalization. Oxford: Oxford University Press.

Burchell, B., Dale, A. and Joshi, H. (1997). Part-time work among British women. In Blossfeld, H. P. and Hakim, C. (Eds.), Between Equalization and Marginalization. Women working part-time in Europe and the United States of America. Oxford: Oxford University Press.

Cockburn, C. (1988). The gendering of jobs: workplace relations and the reproduction of sex segregation. In Walby, S. (Ed.), Gender Segregation at Work. Milton Keynes: Open University Press.

ConstructionSkills (2005). Image and Recruitment, available from: <http://www.constructionskills. net/ sectorskillsagreement/ourchallenges/ $>$ [accessed 1 May 2005].

Crompton, R. (2006). Employment and the Family. Cambridge: Cambridge University Press.

Crompton, R. (Ed.), (1999). Restructuring Gender Relations and Employment. Oxford: Oxford University Press.

Dainty, A., Bagilhole, B. and Neale, R. (2000). A grounded theory of women's career under-achievement in large UK construction companies. Construction Management and Economics, 18, 239-250.

Dainty, A., Bagilhole, B. and Neale, R. (2001). Male and female perspectives on equality measures for the UK construction sector. Women in Management Review, 16, 279-307.

Dex, S. and Joshi, H. (1999). Careers and motherhood: policies for compatibility. Cambridge Journal of Economics, 23, 641-659.

Dex, S. and Walters, P. (1989). Women's occupational status in Britain, France and the USA: explaining the difference. Industrial Relations Journal, 20, 203-212.

DfES (2003). 21st Century Skills, Realising Our Potential. Department for Education and Skills. London: HMSO.

DfES (2005). Skills: Getting on in Business, Getting on at Work. Department for Education and Skills. London: HMSO.

Dooreward, H., Hendrickx, J. and Verschuren, P. (2004). Work orientations of female returners. Work, Employment and Society, 18, 7-28.

DTI (2002). Maximising Returns to Science Engineering and Technology Careers. Department for Trade and Industry. London: HMSO.

DTI (2006). How the Sector Skills Councils are addressing diversity and some good practice case studies. Department for Trade and Industry. London: DTI Publications.

Duncan, S. (2002). Policy discourses on 'reconciling work and life' in the EU. Social Policy and Society, $1,305-314$.

Elliott, J. (2005). Comparing occupational segregation in Great Britain and the United States. Work, Employment and Society, 19, 153-174.

Elliott, J., Dale, A. and Egerton, M. (2004). Returning to work after childbirth: a longitudinal analysis of the role of qualifications in mothers' return to paid employment. In Marshall, V., Heinz, W. R., Kreuger, H. and Verma, A. (Eds.), Restructuring Work and the Life Course. Toronto: University of Toronto Press.

Elliott, J., Dale, A. and Egerton, M. (2001). The influence of qualifications on women's work histories, employment status and earnings at age 33. European Sociological Review, 17, 145-168.

England, P. (2005). Gender Inequality in labor markets: the role of motherhood and segregation. Social Politics, 12, 264-288.

EOC (2005). Then and Now: 30 years of the Sex Discrimination Act. Manchester: Equal Opportunities Commission.

ESS (2001). Employers Skills Survey, Hogarth, T., Wilson, R.A. and IFF Research Limited. Colchester, Essex: UK Data Archive.

European Commission (2002). Employment in Europe 2001. Luxembourg: Office for Official Publications of the European Communities.

European Commission (2003). Employment in Europe 2002. Luxembourg: Official Publications of the European Communities.

Fagan, C. (2001). Time, money and the gender order: work orientations and working-time preferences in Britain. Gender, Work and Organization, 8, 239-266.

Fagan, C., Molto, M., Figueiredo, H., Silvera, R. et al. (2002). Indicators relating to reconciling work and family life. In Rubery, J., Fagan, C., Grimshaw, D., Figueirdeo, H. et al. (Eds.), Indicators on Gender Equality in the European Employment Strategy. Available from: <http:// ec.europa.eu/employment_social/employment_ analysis/gender/indic_gender_equal_in_ess.pdf $>$ [accessed 15 September 2008].

Gallie, D. (1996). Skill, gender and the quality of employment. In Crompton, R., Gallie, D. and Purcell, K. (Eds.), Changing Forms of Employment. London: Routledge.

Gambles, R., Lewis, S. and Rapoport, R. (2006) Global stories from the front line. Introduction in The 
Myth of Work-life Balance. Chichester: Wiley \& Sons.

Grant, L., Yeandle, S. and Buckner, L. (2005). Working below Potential: Women and Part-Time Work. Working Paper No. 40, Manchester: Equal Opportunities Commission.

Hakim, C. (1996). Key Issues in Women's Work. London: Athlone.

Hakim, C. (1997). A sociological perspective on parttime work. In Blossfeld, H. P. and Hakim, C. (Eds.), Between Equalization and Marginalization. Oxford: Oxford University Press.

Hakim, C. (2000). Work-Lifestyle Preferences in the $21^{\text {st }}$ Century. Oxford: Oxford University Press.

Helsinki Group (2002). Women and Science: Review of the Situation in the United Kingdom. Department for Trade and Industry, London: The Stationery Office.

Horrell, S., Rubery, J. and Burchell, B. (1990). Gender and Skills. Work, Employment and Society, 4, 189-216.

Jenkins, S. (2004). Restructuring flexibility: case studies of female part-time workers in six workplaces. Gender, Work and Organization, 11, 306-333.

Kenjoh, E. (2005). New mothers' employment and public policy in the UK, Germany, the Netherlands, Sweden and Japan. Labour, 19, 5-49.

Liff, S. and Ward, K. (2001). Distorted views through the glass ceiling: the construction of women's understandings of their promotion and senior management positions. Gender, Work and Organization, 8, 19-35.

Lewis, S. (2001). Restructuring workplace cultures: the ultimate work-family challenge? Women in Management Review, 16, 21-29.

Mackenzie, S., Kilpatrick, A. R. and Akintoye, A. (2000). UK construction skill shortages response strategies and an analysis of industry perceptions. Construction Management and Economics, 18, 853-862.

Macran, S., Joshi, H. and Dex, S. (1996). Employment after childbearing: a survival analysis. Work, Employment and Society, 10, 273-296.

Manning, A. and Petrongolo, B. (2004). The Part-Time Pay Penalty. Department for Trade and Industry, Women and Equality Unit. DTI Publications Online available from: <www.dti.gov.uk $>$ [accessed 29 August 2007].

McRae, S. (1993). Returning to work after childbirth: opportunities and inequalities. European Sociological Review, 9, 125-138.
McRae, S. (1994). Labour supply after child birth: do employers' policies make a difference? Sociology, 28, 99-122.

Miller, L., Neathley, F., Pollard, E. and Hill, D. (2004). Occupational Segregation, Gender Gaps and Skill Gaps. EOC Working Paper No. 15, available from $<$ http://www.employment-studies.co.uk/pubs/summary.php?id=eocwps15 $>$ [accessed 15 May 2008].

OECD (2007). Statistical Annex. OECD Employment Outlook, Paris: OECD.

Olsen, W. K. and Walby, S. (2004). Modelling Gender Pay Gaps. Working Paper No. 17, Manchester: Equal Opportunities Commission.

Olsen, W. K. and Morgan, J. (2005). A critical epistemology of analytical statistics: addressing the sceptical realist. Journal for the Theory of Social Behaviour, 35, 255-284.

ONS (2001). Labour Force Survey, Office for National Statistics. Social and Vital Statistics Division and Northern Ireland Statistics and Research Agency. Central Survey Unit, Colchester, Essex: UK Data Archive.

ONS (2006). Economic activity and inactivity. Labour Market Trends. London: The Stationery Office, p. 88.

Peters, J., Lane, N., Rees, T. and Samuels, G. (2003). SET Fair: A report on Women in Science, Engineering, and Technology from Baroness Greenfield CBE. Department for Trade and Industry. London: DTI Publications.

Rose, M. (2001). Closing down a Work Career: Housework, Employment Plans and Women's Work Attitudes. ESRC Working Paper 1, Transitions and Careers. Bath: University of Bath.

Ruiz, Y. (2004). Skill shortages in skilled construction and metal trade occupations. Labour Market Trends, Vol. 112. London: ONS, p. 10.

Rubsamen-Waigmann, H., Sohlberg, R., Rees, T., Berry, O. et al. (2003). Women in Industrial Research: A wake up call for European industry. Luxembourg: Office for Official Publications of the European Communities.

Singh, V. and Vinnicombe, S. (2000). Gendered meanings of commitment from high technology engineering managers in the United Kingdom and Sweden. Gender, Work and Organization, 7, 1-19.

SSDA, (2004). The UK Skills and Productivity Agenda: The Evidence Base for the SSDA's Strategic Plan 2005-2008. Research Report 8, September, available from: <www.skillsforbusiness.org.uk $>$ [accessed 1 May 2005]. 
Thornley, C. (2007). Working part-time for the State. Gender, class and the public sector pay gap. Gender, Work and Organization, 14, 454-475.

Tomlinson, J. (2006). Part-time occupational mobility in the service industries: regulation, work commitment and occupational closure. The Sociological Review, 54, 66-86.

Tomlinson, J. (2007). Employment regulation, welfare and gender regimes: a comparative analysis of women's working-time patterns and work-life balance in the UK and the US. International Journal of Human Resource Management, 18, 401-415.

Tomlinson, J., Olsen, W., Neff, D. and Purdam, K. (2005). Examining the Potential for Women Returners to Work in Areas of High Occupational Gender Segregation. Department for Trade and Industry. London: DTI Publications, pp. 1-106.

Walby, S. (1997). Gender Transformations. London: Routledge.

Walby, S., and Olsen, W.K. (2002). The Impact of Women's Position In the Labour Market On Current UK Productivity and Implications for Future Productivity Growth. London: The Department for Trade and Industry, Women and Equality Unit. London: The Stationery Office.
Walters, S. (2005). Making the best of a bad job? Female part-timers' orientations and attitudes to work. Gender, Work and Organization, 12, 193-216.

Women and Work Commission (2006). Women and Work Commission: Shaping a Fairer Future. Department for Trade and Industry. London: DTI Publications.

\section{Authors' Addresses}

J. Tomlinson (to whom correspondence should be addressed), Leeds University Business School, University of Leeds, Leeds, LS2 9JT, UK. Tel: +44 (0)113 343 4482; Fax: +44 (0)113 343 4885; Email: j.tomlinson@leeds.ac.uk

W. Olsen, Centre for Census and Survey Research, University of Manchester, Manchester, M13 9PL, UK. Email: wendy.olsen@manchester.ac.uk

K. Purdam, Centre for Census and Survey Research, University of Manchester, Manchester, M13 9PL, UK. Email: kingsley.purdam@manchester.ac.uk

Manuscript received: August 2007 